Review

\title{
A Review of Entomopathogenic Nematodes as a Biological Control Agent for Red Palm Weevil, Rhynchophorus ferrugineus (Coleoptera: Curculionidae)
}

\author{
Wan Nurashikin-Khairuddin ${ }^{1,2}$, Siti Noor Aishikin Abdul-Hamid ${ }^{3}$, Mohammad Saiful Mansor ${ }^{1}$, \\ Izwan Bharudin ${ }^{1}\left(\mathbb{D}\right.$, Zulkefley Othman ${ }^{4}$ (D) and Johari Jalinas ${ }^{1,2, *(\mathbb{D})}$
}

check for

updates

Citation: Nurashikin-Khairuddin, W. Abdul-Hamid, S.N.A.; Mansor, M.S.; Bharudin, I.; Othman, Z.; Jalinas, J. A Review of Entomopathogenic Nematodes as a Biological Control Agent for Red Palm Weevil, Rhynchophorus ferrugineus (Coleoptera: Curculionidae). Insects 2022, 13, 245. https://doi.org/ $10.3390 /$ insects 13030245

Academic Editor: Itamar Glazer

Received: 14 January 2022

Accepted: 24 February 2022

Published: 28 February 2022

Publisher's Note: MDPI stays neutral with regard to jurisdictional claims in published maps and institutional affiliations.

Copyright: (C) 2022 by the authors. Licensee MDPI, Basel, Switzerland. This article is an open access article distributed under the terms and conditions of the Creative Commons Attribution (CC BY) license (https:// creativecommons.org/licenses/by/ $4.0 /)$
1 Department of Biological Sciences and Biotechnology, Faculty of Science and Technology, Universiti Kebangsaan Malaysia, Bangi 43000, Selangor, Malaysia; p107241@siswa.ukm.edu.my (W.N.-K.); msaifulmansor@ukm.edu.my (M.S.M.); ibb@ukm.edu.my (I.B.)

2 Centre for Insect Systematics, Faculty of Science and Technology, Universiti Kebangsaan Malaysia, Bangi 43600, Selangor, Malaysia

3 Agrobiodiversity and Environment Research Centre, MARDI Headquarters, Serdang 43400, Selangor, Malaysia; ctaikina@mardi.gov.my

4 Department of Biomedical Sciences, Faculty of Medicine and Health Sciences, Universiti Putra Malaysia (UPM), Serdang 43400, Selangor, Malaysia; zulkefley_os@upm.edu.my

* Correspondence: johari_j@ukm.edu.my

Simple Summary: The red palm weevil, Rhynchophorus ferrugineus, is a significant pest to palm plantations globally and directly impacts economic activities. These weevils' cryptic attack on palms is inconspicuous until the damage is irreparable. Chemical pesticides were used extensively in plantations to mitigate RPW infestation, and the results were impressive. However, their negative impact on the environment, nontarget organisms, and insecticide resistance is a primary concern. Therefore, alternative preventive and curative solutions based on the natural enemy concept are safer for the environment and more sustainable. This review highlights the use of entomopathogenic nematodes and their symbiotic bacteria as biological control agents against the red palm weevil and storage formulation.

Abstract: Rhynchophorus ferrugineus (Olivier) (Coleoptera: Curculionidae) is a severe pest of palm trees worldwide. The development and feeding activities of $R$. ferrugineus larvae inside the trunk damage palm trees. However, the absence of noticeable infestation signs at an early stage contributes to the spread of the attack. Integrated pest management (IPM) has been introduced to control $R$. ferrugineus infestation by implementing various approaches and techniques. The application of chemical pesticides has shown impressive results. However, biological control should be applied as an alternative solution due to adverse environmental impacts and pest resistance issues. One example is the use of entomopathogenic nematodes (EPNs) as biological control agents, which can forage and attack targeted pests without compromising the environment and other nontarget organisms. EPNs and their symbiotic bacteria have a mutualistic interaction that can kill the host within a short period of time. Therefore, this review emphasizes the effectiveness of entomopathogenic nematodes and their symbiotic bacteria against $R$. ferrugineus.

Keywords: Rhynchophorus ferrugineus; palm infestation; Steinernema; Heterorhabditis; symbiotic bacteria; biological control

\section{Introduction}

The red palm weevil (RPW), Rhynchophorus ferrugineus (Olivier) (Coleoptera: Curculionidae), is the primary pest of date palm (Phoenix dactylifera), canary palm (Phoenix canariensis), coconut (Cocos nucifera), and other palm trees [1-4]. Approximately 40 palm species are host to the RPW, with the majority being from the Arecaceae family, with one 
species each from Agavaceae and Poaceae [5]. Malaysia first recorded three Rhynchophorus species, i.e., R. ferrugineus in Peninsular Malaysia, Sabah, and Sarawak; Rhynchophorus vulneratus (Panzer) in Peninsular Malaysia and Sarawak; and Rhynchophorus bilineatus (Montrouzier) in Sarawak only [2,6].

RPW infestation has resulted in additional costs to the ornamental and cultivation palm industries, as it involves eradication and treatment processes [7]. Various preventive or curative approaches are currently being applied to combat RPW infestation on palm trees, including physical and chemical detection with chemical and biological control approaches [8,9]. Entomopathogenic nematodes (EPNs) are one of the biological control agents used in integrated pest management (IPM) programs, as they are lethal obligate parasites and safe to the environment. The role of EPNs is similar to entomopathogenic fungi and bacteria in reducing and replacing the use of chemical insecticides [10,11]. Much research has been conducted to test the pathogenicity of EPNs as potential biological control agents of the RPW and their effectiveness in the field. The efficacy of EPNs against the targeted host is diverse, depending on the species or strain. Therefore, this paper discusses the role and application of EPNs as biological control agents in managing RPW infestation in the field.

\section{Biology and Distribution of R. ferrugineus}

The genus Rhynchophorus consists of ten species distributed in specific regions [4]. Rhynchophorus cruentatus (F.) is found in the coastal areas of South Carolina through to the Florida Keys and west into coastal Texas in the USA [12,13]. Rhynchophorus palmarum (L.) is native to Mexico, Central and South America, the Caribbean, and Southern California USA [14,15]. Rhynchophorus ritcheri (Wattanapongsiri) is native to Peru, Rhynchophorus quadrangulus (Quedenfeld) from West to Central Africa, and Rhynchophorus phoenicis (F.) in tropical Africa [16-18]. Rhynchophorus bilineatus is native to New Guinea and Papua, Rhynchophorus distinctus (Wattanapongsiri) in Borneo, Rhynchophorus lobatus (Ritsema) in Sumatera, and R. ferrugineus in Oriental Asia [4]. R. vulneratus is native to Southeast Asia, was discovered, and subsequently eradicated from California $[19,20]$. R. ferrugineus and $R$. vulneratus are classified as synonymous and color morphs of the same species based on cytochrome oxidase gene sequence and morphological characteristics [21]. Based on these data, $R$. vulneratus should also be known as R. ferrugineus. However, DNA sequences of mitochondrial COI data [22], with COI and Cytb molecular clock analysis [23], have proved that $R$. ferrugineus and $R$. vulneratus are two different species.

The RPW originated from South and Southeast Asia by infesting coconut palms, C. nucifera, and was later detected in the Middle East region [24], where it became the key pest of the date palm (P. dactylifera). Eventually, the infestation continued to North Africa [25], and Spain was the first country in Europe to report RPW presence in 1993 [26]. The canary and date palms have been the main factors for the rapid expansion of the RPW throughout the Mediterranean during the last two decades [3,27]. In Southeast Asian countries, RPW infestation is not only limited to coconut (C. nucifera) but also other important economic plants such as oil palm (Elaeis guineensis), sago palm (Metroxylon sagu), and sugar palm (Arenga pinnata), as well as ornamental plants such as ribbon palm (Livistona decipiens) and Chinese fan palm (Livistona chinensis) [6,9,28,29]. The RPW quickly bores of young palm below 20 years. as the trunk is soft and tender [30-32].

RPWs have four phases in their life cycle: eggs, larvae, pupae, and adults. Corresponding to several articles, the eggs deposited by adult female RPWs vary, ranging from 180 eggs to 396 eggs [33-37]. Depending on where the attack begins along the palm tree, adult females lay eggs in wounds or openings at the palm crown or leaf scar [35]. The complete life cycle of the RPW varies from 45 days to 180 days [2,3]. Once hatched, larvae will start to feed on the soft tissue. Continuous feeding activities will create tunnels along the stem before the larvae develop into pupae inside an oval-shaped cocoon made of palm fibers $[6,8,35]$. 
The duration of the larval development phase, which can range from 24 to 210 days, is influenced by diet and temperature, while the host plant species determines the number of larval instars $[9,38]$. RPWs tend to have a shorter development period if the environment and host plant are favorable to insects [39]. The plant host species influences the fertility of females RPWs [33]. RPWs are reared in laboratory facilities for their continuous supplies in various research, and their diet mainly comes from abundant and nearby sources. Norzainih et al. [40] successfully reared RPWs in the laboratory by feeding them sugarcane and reported the production of eight larval instars within 80 days. In another study, ElZogby and Abdel-Hameid [41] demonstrated that a sugarcane diet produced 12 instar larvae in 89 days. Different ambient temperatures are likely to be the cause of these inconsistent results. Furthermore, within a year, RPWs can produce $3 \mathbf{- 4}$ generations or more in a single palm tree $[42,43]$.

\section{Red Palm Weevil Infestation}

$R$. ferrugineus infestation on canary palms can be classified into five stages, according to Güerri-Agulló et al. [44]. The first level of early infestation begins with the absence of visual indicators of RPW assault on the palm tree and progresses to the formation of pits and notches in the leaves at the second level. The third and fourth stages are characterized by uneven leaves in the crown, with frond skirting pointing downwards. Finally, the palms die in the last stage.

In oil palm, the RPW infestation level can be classified into the early, intermediate I and II, and final stage. The intermediate stage can be detected as early as the fourth week of the attack with sawdust at the trunk's base and visible dark sap accompanied by odor from the fermentation process. Consequently, the fronds begin to collapse, and at the final stage, the collapsed fronds turn brown. Early and intermediate infestation can be treated by injecting insecticides into the trunk. The final stage requires the trees to be eradicated by cutting them down according to the guidelines provided [45].

\section{Control Management of the Red Palm Weevil}

Several implementations have been performed to manage RPW infestation, including trapping and monitoring, preventive and curative techniques, and plant quarantine treatments $[3,38,46,47]$. Preventive and curative treatment should be performed at the early stage of pest infestation to protect the palm from further damage and for recovery of the infested palm [5]. The trapping technique involves using pheromones, with both chemical synthesis and food bait showing significant decreases in RPW infestation. However, synthetic food baits are better than natural food baits since they can attract more weevils and can survive over a longer period [48]. Insecticides based on carbamate, organophosphate, phenylpyrazole, and neonicotinoid are used for preventative and curative treatments [38,47,49]. Early detection of RPW infestation can be performed using a trained dog to detect the foul odor of infested trees $[9,16]$. Alternatively, acoustic detection can be achieved by detecting the feeding activities of larvae within the stem [27,50-52]. Several techniques have been applied to control weevil infestation in coconut plants in Malaysia. These include pheromone traps and chemical and physical controls eradicating the infested palm. The chemical controls involve spraying Cypermethrin on the crown, canopy, and stem of the palm and trunk injection with Methamidophos or Monocrotophos [53].

Management of RPW infestation within the palm trunk is also possible by using biological control agents such as EPNs, as they can penetrate, invade, and kill its prospective pests [54]. Much research has been carried out on the effectiveness of entomopathogenic nematodes (EPNs) against insect pests, especially on the RPW [55]. Besides EPNs, Metarhizhium anisopliae and Beuveria bassiana are entomopathogenic fungi commonly applied in IPM to kill RPWs in the field [56-58]. The pathogenicity of indigenous isolates, M. anisopliae strain MET-GRA4 against adult red palm weevils (RPWs), was investigated in vitro with different spore viabilities. The isolates were pathogenic, with 100\% mortality 21 days after infection [58]. 
The only virus found in the RPW is the highly potent cytoplasmic polyhedrosis virus (CPV). The virus was first discovered in Kerala, India, where it infected all stages of the RPW. During the late larva stage, infection resulted in malformed adults and significantly reduced insect populations $[59,60]$. The efficacy of Bacillus thuringiensis (Bt), an entomopathogenic bacterium characterized by its production of insecticidal crystal proteins on larvae and adults of $R$. ferrugineus, was also studied. Infection with $B$. thuringiensis subspecies kurstaki identified from Egyptian larvae successfully controlled the RPW in laboratory conditions $[60,61]$. A study using commercial bacteria-based biopesticide reported the RPW larval mortality was high $(>50 \%)$ at the lowest concentration $(0.5 \mathrm{mg} / \mathrm{mL})$, and it reached $85 \%$ at $2.0 \mathrm{mg} / \mathrm{mL}$ [62]. Larvae and adult mortality ranged between $46.86-58.36 \%$ and 26.79-39.04\%, respectively, after 21 days of exposure to $B$. thuringiensis var. kurstaki [63].

Additionally, microwave heating treatment is another approach used to combat pest issues, such as R. ferrugineus infestation, without causing any significant harm to the host plant [64-66]. Microwave radiation causes hyperthermia in $R$. ferrugineus adults and larvae. This method is safe for the environment and only causes slight dehydration in palm trees [67]. Several plants, such as the French marigold (Tagetes patula) [68], Ceylon (Cinnamomum zeylanicum) [69], citronella grass (Cymbopogon nardus) [70,71], clove (Syzygium aromaticum), and cardamom (Elettaria cardamomum), are known for their insecticidal properties and have been proven to effectively kill the RPW [72].

\section{Biology of Entomopathogenic Nematodes}

Nematodes are microscopic, multicellular, and nonsegmented bodies of worms under the phylum Nematoda. Nematodes have adapted to live in various environments and have symbiotic relationships with other organisms [73]. The life cycle consists of the egg stage, four larval stages, and adult stage [74]. The life cycle of EPN is 5-10 days, depending on temperature, bacterial symbiont, and ability to suppress the immunity of the insect host $[75,76]$. EPNs are widely distributed, but the species varies according to geographic regions and habitats $[77,78]$. There are 30 families of nematodes associated with insects, plants, and vertebrates [79]. Steinermatidae and Heterorhabditidae are significant families widely used as control agents of insects. Currently, there are two genera in Steinernematidae, Steinernema Travassos, 1927 (comprises over 30 species), and Neosteinernema Nguyen and Smart, 1994 (one species, Neosteinernema longicurvicauda). On the other hand, Heterorhabditidae is solely represented by the genus Heterorhabditis Poinar 1976 and one species, Heterorhabditis bacteriophora [80,81]. However, Hunt and Nguyen reported that 95 valid species of Steinernema and 16 species of Heterohabditis were described by the end of 2015 [82].

A symbiotic Gram-negative bacterium, genus Xenorhabdus in Steinernema and Photorhabdus in Heterorhabditis, lives in the modified intestines of infective juvenile (IJ) nematodes $[83,84]$. When the IJ invade their specific host after entering via the anus, spiracle, and mouth, the symbiotic bacteria released by the IJs in the hemocoel of the target insect multiply and cause the death of the insects within $24-48 \mathrm{~h}$ due to septicemia $[85,86]$. In addition, the symbiotic bacteria produce secondary metabolites that cause cytotoxic activity. It will cause the hemolymph immunodepression of the insect, thus leading to septicemia and death of the host [87]. The secondary metabolites produced by the symbiotic bacteria also inhibit other bacteria, fungus, and protists from developing in the nutrient-rich hemolymph of the dead cadaver, thus providing a suitable condition for the nematodes to reproduce [88,89]. The IJs feed on the multiplied bacteria and digested host tissue until all the sources are depleted and begin to search for a new host [90]. As a result, only infective juvenile (IJ) or dauer larva can survive outside the host [86] (Figure 1). The brown color of the insect cadaver indicates the insect was killed by Steinernematid nematodes, while the red color indicates Heterorhabditid species. The color difference is due to the pigment released by the symbiotic bacteria in the cadaver $[80,85]$. 


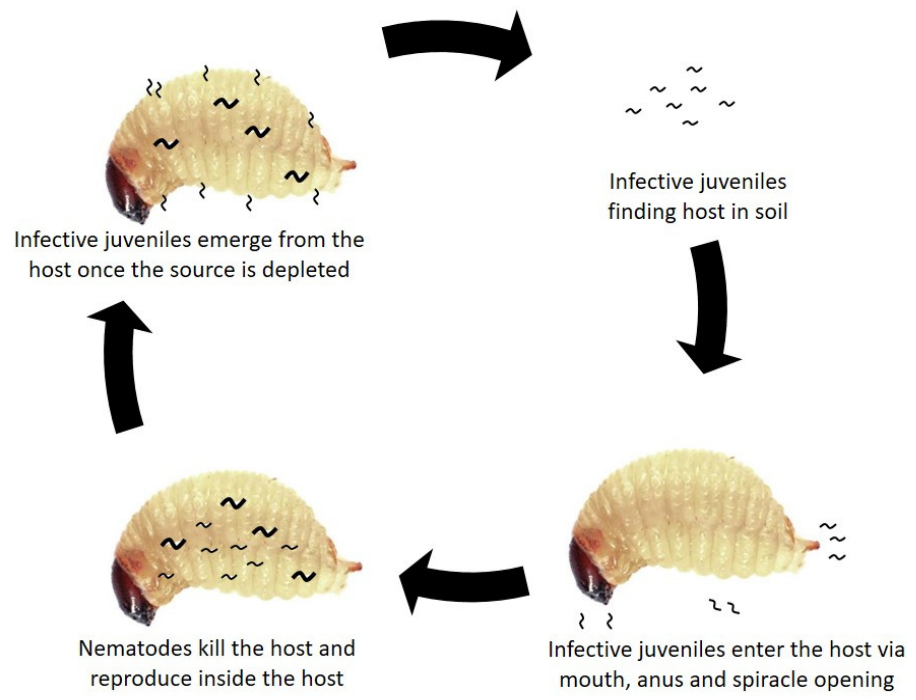

Figure 1. Illustration of invasion of entomopathogenic nematodes on insect host.

\section{Mutualistic Symbiotic Bacteria}

In association with Steinernema and Heterorhabditis, 21 Xenorhabdus spp. and 3 Photorhabdus spp. have been described, respectively $[88,91,92]$. The Steinernema and Heterorhabditis species can be identified through $28 \mathrm{~S}$ rDNA and ITS regions' sequencing and PCR-based analysis [88]. Steinernematid reproduces via cross-fertilization between males and females and Heterorhabditid via self-fertile hermaphrodites [90,93,94]. In addition, Heterorhabditid is able to produce hermaphrodites, males, and females in the subsequent generations [95].

The symbiotic bacteria, Xenorhabdus and Photorhabdus, are essential to the EPN. They kill the insect host in a short period, providing a suitable environment for the EPN to reproduce and produce antibiotics and secondary metabolites that prevent any development of other microorganisms and convert the host tissue into food [96]. In exchange, the EPN provides protection and access to the host's hemolymph [97]. However, in this bacteriumnematode complex, nematodes are responsible for overcoming the host immunological defense by making lipid or protein [98-100]. Thus, the bacterium-nematode complex plays a vital role against insect hosts.

The bacteria Xenorhabdus spp. and Photorhabdus spp. exist in two phenotypes, primary and secondary [101]. The first-phase bacteria are smaller, 3-4 $\mu \mathrm{m}$ in length, and induce more secretory enzymes, toxins, antibiotics, and protein with the oval or circular shape. The secondary bacteria are larger, 6-7 $\mu \mathrm{m}$ in length, and do not produce enzymes or antibiotics or flat colonies. The primary bacteria only reside in the insect's body for a few hours after being released by the nematodes before being converted to secondary bacteria. The transformation is believed to adapt to the external environment [102]. Research conducted on X. stockiae and P. luminescens subsp. Akhurstii [88] against Aedes aegypti and Aedes albopictus has shown that the symbiotic bacteria are malicious against mosquitoes and demonstrated that they could be utilized as biological control agents.

\section{Application of Entomopathogenic Nematodes as Biological Control Agent}

The nematodes use two basic strategies in finding a host: active searching, i.e., cruising or foraging, and the passive method by waiting for the host to contact with the nematodes and ambush [94]. As a result, the EPN can reach its specific host even in a sealed area such as a tree trunk. Major target insects of EPNs in IPM are Coleoptera and Lepidoptera, but it also applies to other orders, such as Thysanoptera, Diptera, Orthoptera, Blattodea, Hymenoptera, and Siphonaptera [81]. Besides that, the application of EPNs against insect pests in the orchard system also contributes to promising results [103]. Shahina et al. [104] conducted a laboratory bioassay of seven EPNs species against all life stages of the RPW, including the eggs. All seven EPNs species killed all stages of the RPW, but the emergence 
of IJs from the adult RPW was recorded in Steinernema pakistanense. However, a single species of EPNs does not have the same virulence towards all stages of the RPW [104,105]. For instance, Steinernema scapterisci, Steinernema sp. (SII), Steinernema abbasi are virulent to the adult stage, while Heterorhabditis bacteriophora is virulent to the larvae stage. However, both stages are susceptible to Steinernema glaseri.

\section{Biological Assay on Pathogenicity of Entomopathogenic Nematodes against R. ferrugineus}

Various studies on the efficacy of EPNs against the RPW have been conducted, particularly in the Mediterranean, Middle East, and Southern Asia (Table 1). Steinernema carpocapsae caused the highest mortality of RPW larvae at $98.9 \%$ after eight days of treatment under laboratory conditions, followed by H. bacteriophora at $86.9 \%$ and Steinernema feltiae at 38.9\% [55]. The efficacy assessment of EPNs was conducted in the date palm field in the UAE [106], where a local isolate of Heterorhabditis indicus appeared to kill larvae, adults, and cocoons, of the RPW successfully within a short period when compared to Steinernema riobrave and S. abbasi. The RPW population in the date palm field also showed a successful decline after the second treatment within two months. Due to their high pathogenicity against insect hosts [34], the two common EPNs are utilized as biological control agents in IPM are S. carpocapsae Weiser and H. bacteriophora Poinar [107], as shown in Table 1.

Table 1. Summary of the pathogenicity assay on red palm weevil by using the entomopathogenic nematode.

\begin{tabular}{|c|c|c|c|c|c|}
\hline Author & Species & Bioassay & Result & $\begin{array}{c}\text { Symbiotic } \\
\text { Bacteria }\end{array}$ & $\begin{array}{l}\text { Origin/ } \\
\text { Country }\end{array}$ \\
\hline [55] & $\begin{array}{l}\text { S. corpocapsae } \\
\text { S. feltiae } \\
\text { H. bacteriophora }\end{array}$ & $\begin{array}{l}\text { Concentrations: } 100 \mathrm{IJs} \\
\text { each larva and adult } \\
\text { RPW: 3rd, 6th, 10th } \\
\text { larvae, adult } \\
\text { Duration: } 12 \text { h duration } \\
\text { up to } 8 \text { days }\end{array}$ & $\begin{array}{c}\text { Mortality: } \\
\text { S. corpocapsae } \\
\text { 3rd: } 96.5 \% \text {, 6th: } 94.7 \% \text {, } \\
\text { 10th: } 88.17 \% \text {, } \\
\text { Adult: } 3.07 \% \\
\text { S. feltiae } \\
\text { 3rd: } 38.68 \% \text {, 6th: } 36.35 \% \text {, } \\
\text { 10th: } 35.35 \% \text {, Adult: } 0 \% \\
\text { H. bacteriophora } \\
\text { 3rd: } 85.75 \%, 6 \text { th: } 78.15 \% \text {, } \\
\text { 10th: } 74.4 \%, \\
\text { Adult: } 0.66 \%\end{array}$ & $\mathrm{~N} / \mathrm{A}$ & Pakistan \\
\hline [34] & $\begin{array}{c}\text { S. affine } \\
\text { S. carpocapsae } \\
\text { S. feltiae } \\
\text { H. bacteriophora }\end{array}$ & $\begin{array}{l}\text { RPW: Last instar larvae } \\
\text { Concentrations: } \\
500 \text { IJs / larva } \\
\text { Duration: mortality } \\
\text { recorded after } 7 \text { th day }\end{array}$ & $\begin{array}{l}\text { Greatest mortality in } H . \\
\text { bacteriophora and least in } \\
\text { S. affine }\end{array}$ & $\mathrm{N} / \mathrm{A}$ & Turkey \\
\hline [108] & $\begin{array}{c}\text { H. bacteriophora } \\
\text { S. abbasi } \\
\text { S. anomali } \\
\text { S. carpocapsae } \\
\text { S. feltiae } \\
\text { S. glaseri } \\
\text { S. riobravae } \\
\text { Steinernema sp. } \\
\text { S. ritterai (EGBS) } \\
\text { S. egyptens } \\
\text { S. kushidai } \\
\text { Heterorhabditis sp. }\end{array}$ & $\begin{array}{c}\text { Concentration: } \\
2000 \text { IJs/mL } \\
\text { RPW: } 5 \text { weevils in a box } \\
\text { (young, medium, } \\
\text { full-grown larvae, pupa } \\
\text { with cocoon, and adult) } \\
\text { Duration: mortality } \\
\text { recorded every } 2 \text { days } \\
\text { for } 10 \text { days }\end{array}$ & $\begin{array}{l}\text { Some EPNs showed a } \\
\text { preference for certain life } \\
\text { stages of weevils. } \\
\text { Steinernema sp. showed } \\
\text { the highest mortality, } \\
\text { and S. feltiae was the } \\
\text { least virulent species }\end{array}$ & $\mathrm{N} / \mathrm{A}$ & Egypt \\
\hline
\end{tabular}


Table 1. Cont.

\begin{tabular}{|c|c|c|c|c|c|}
\hline Author & Species & Bioassay & Result & $\begin{array}{c}\text { Symbiotic } \\
\text { Bacteria }\end{array}$ & $\begin{array}{l}\text { Origin/ } \\
\text { Country }\end{array}$ \\
\hline [98] & S. carpocapsae & $\begin{array}{c}\text { The antimicrobial } \\
\text { response of RPW larvae } \\
\text { on S. carpocapsae and X. } \\
\text { nematophila }\end{array}$ & $\begin{array}{l}\text { Living EPNs and } \\
\text { symbionts can suppress } \\
\text { the antimicrobial } \\
\text { response of the RPW }\end{array}$ & $\begin{array}{c}\text { X. } \\
\text { nematophila }\end{array}$ & Netherlands \\
\hline [105] & $\begin{array}{c}\text { S.scapterisci Steinernema sp. } \\
\text { S. abbasi } \\
\text { S. glaseri } \\
\text { H. bacteriophora }\end{array}$ & $\begin{array}{l}\text { RPW: Five late instar } \\
\text { larvae and an adult. } \\
\text { Concentration: } \\
\text { (156-2000 IJs } / \mathrm{mL} \text { ) of } \\
\text { EPN injected into } \\
\text { hemocoel. } \\
\text { Duration: } 10-13 \text { days }\end{array}$ & $\begin{array}{c}\text { Adults are more } \\
\text { resistant than the larva } \\
\text { stage. S.glaseri and } H \text {. } \\
\text { bacteriophora exhibited } \\
\text { high virulence toward } \\
\text { the RPW larvae }\end{array}$ & $\mathrm{N} / \mathrm{A}$ & Egypt \\
\hline [106] & $\begin{array}{l}\text { H. indicus } \\
\text { S. riobrave } \\
\text { S. abbasi }\end{array}$ & $\begin{array}{c}\text { Concentration: } \\
(50,100,200,400, \text { and } \\
800 \text { IJs }) \\
\text { Duration: } 60 \mathrm{~h} \text { and } \\
6 \text { days }\end{array}$ & $\begin{array}{l}\text { The local isolate of } H \text {. } \\
\text { indicus is highly } \\
\text { pathogenic towards } \\
\text { adult RPWs }\end{array}$ & $\mathrm{N} / \mathrm{A}$ & UAE \\
\hline [99] & S. carpocapsae & $\begin{array}{l}\text { Immune response of the } \\
\text { RPW after infection and } \\
\text { post-infection of EPN }\end{array}$ & $\begin{array}{c}\text { The EPN can short-term } \\
\text { regulate the } \\
\text { phenoloxidase activity } \\
\text { for its continuity }\end{array}$ & $\mathrm{N} / \mathrm{A}$ & Netherlands \\
\hline [54] & $\begin{array}{l}\text { S. carpocapsae } \\
\text { H. bacteriophora }\end{array}$ & $\begin{array}{l}\text { RPW: Various stages of } \\
\text { the RPW (small, } \\
\text { medium and large } \\
\text { larvae, pupae } \\
\text { and adults) } \\
\text { Concentration: } 50- \\
6000 \text { IJs } / 0.4 \mathrm{~mL} \text { water } \\
\text { Duration: Mortality } \\
\text { recorded after } 72 \mathrm{~h}\end{array}$ & $\begin{array}{l}\text { Increase size of the host } \\
\text { reduces its susceptibility } \\
\text { Small larvae-500 IJs } \\
\text { Medium larvae- } \\
\text { 2000/6000 IJs } \\
\text { Large larvae-6000 IJs } \\
\text { Pupae/adults—2000 IJs }\end{array}$ & $\mathrm{N} / \mathrm{A}$ & Germany \\
\hline [104] & $\begin{array}{l}\text { S. pakistanense } \\
\text { S. asiaticum } \\
\text { S. abbasi } \\
\text { S. siamkayai } \\
\text { S. feltiae } \\
\text { H. indica } \\
\text { H. bacteriophora }\end{array}$ & $\begin{array}{l}\text { RPW: Eggs, first, third, } \\
\text { sixth, final stages } \\
\text { larvae, adult } \\
\text { Concentration: } \\
50-1500 \mathrm{IJs} / \mathrm{mL} \\
\text { Period: Mortality was } \\
\text { recorded between } 24 \text { to } \\
168 \mathrm{~h}\end{array}$ & $\begin{array}{l}\text { H. bacteriophora and } S . \\
\text { siamkayai showed the } \\
\text { highest mortality of } \\
\text { larvae while all EPNs } \\
\text { showed similar results } \\
\text { in adult RPWs }\end{array}$ & $\mathrm{N} / \mathrm{A}$ & Pakistan \\
\hline [109] & $\begin{array}{c}\text { H. indica } \\
\text { S. carpocapsae }\end{array}$ & $\begin{array}{l}\text { Young and grown } \\
\text { larvae, adult RPW were } \\
\text { infected with EPNs in } \\
\text { the laboratory and date } \\
\text { palm field }\end{array}$ & $\begin{array}{l}\text { In the lab, the mortality } \\
\text { RPWs is from } 70 \% \text { to } \\
100 \% \text {. In the field, the } \\
\text { mortality of adults and } \\
\text { larvae is } 46 \% \text { and } 60 \%\end{array}$ & $\mathrm{~N} / \mathrm{A}$ & UAE \\
\hline [110] & $\begin{array}{c}\text { S. riobravae } \\
\text { S. carpocapsae } \\
\text { Heterorhabditi sp. }\end{array}$ & $\mathrm{N} / \mathrm{A}$ & $\begin{array}{l}\text { All species are virulent } \\
\text { to larvae and adult } \\
\text { RPWs. LC50 of } \\
\text { S. riobravae } \\
\text { S. carpocapsae } \\
\text { Heterorhabditis sp. were } \\
\text { 900, 1100, and } \\
\text { 1416 IJs/weevil. }\end{array}$ & $\mathrm{N} / \mathrm{A}$ & Egypt \\
\hline
\end{tabular}


Table 1. Cont.

\begin{tabular}{|c|c|c|c|c|c|}
\hline Author & Species & Bioassay & Result & $\begin{array}{l}\text { Symbiotic } \\
\text { Bacteria }\end{array}$ & $\begin{array}{l}\text { Origin/ } \\
\text { Country }\end{array}$ \\
\hline [111] & $\begin{array}{c}\text { S. abbasi } \\
\text { S. carpocapsae All } \\
\text { S. carpocapsae S2 } \\
\text { S. riobravae } \\
\text { S. feltiae } \\
\text { S. glaseri } \\
\text { S. anomali } \\
\text { Heterorhabditis sp. IS12 } \\
\text { Heterorhabditis sp. S1 } \\
\text { H. bacteriophora }\end{array}$ & $\begin{array}{c}\text { RPW: Larvae, pupae, } \\
\text { and adults (lab) } \\
2000 \text { IJs/mL Duration: } \\
\text { Mortality was calculated } \\
\text { after } 7 \text { weeks } \\
\text { Field trial: } 3000 \text { IJs /mL } \\
\text { with } 300 \text { mL injected } \\
\text { into the infected tree } \\
\text { Duration: Mortality was } \\
\text { calculated after two } \\
\text { weeks of treatment }\end{array}$ & $\begin{array}{c}\text { In the lab, all EPNs were } \\
\text { virulent to any RPW } \\
\text { stages } \\
\text { In the field, } 66.67 \% \\
\text { mortality of larvae was } \\
\text { caused by } H \text {. } \\
\text { bacteriophora }\end{array}$ & $\mathrm{N} / \mathrm{A}$ & Egypt \\
\hline [112] & H. bacteriophora & $\begin{array}{l}\text { RPW: 2nd, } 4 \text { th, and 6th } \\
\text { instar larval of RPW. } \\
\text { Method: Beauveria } \\
\text { bassiana and Metarhizium } \\
\text { anisopliae combined } \\
\text { treatment } \\
\text { Larval development } \\
\text { was recorded. } \\
\text { Duration: Mortality of } \\
\text { the larvae were recorded } \\
\text { weekly after application }\end{array}$ & $\begin{array}{l}\text { Association of } H \text {. } \\
\text { bacteriophora and } B \text {. } \\
\text { bassiana produced better } \\
\text { results, especially in } \\
\text { early larvae and } \\
\text { decelerated larval } \\
\text { development }\end{array}$ & $\mathrm{N} / \mathrm{A}$ & Pakistan \\
\hline [113] & $\begin{array}{l}\text { H. bacteriophora } \\
\text { H. megidids } \\
\text { H. carpocapsae } \\
\text { S. feltiae } \\
\text { S. glaseri } \\
\text { S. affine } \\
\text { S. longicaudum } \\
\text { S. apuliae } \\
\text { S. kraussel }\end{array}$ & $\begin{array}{l}\text { Concentration: } 300 \text { IJs in } \\
0.5 \text { mL water } \\
\text { RPW: Late instars and } \\
\text { adult RPW } \\
\text { Duration: Mortality was } \\
\text { recorded every } 2 \text { days in } \\
10 \text { days }\end{array}$ & $\begin{array}{c}\text { H. bacteriophora, S. } \\
\text { longicaudum, and } S \text {. } \\
\text { carpocapsae were highly } \\
\text { virulent towards larvae } \\
\text { and adult RPWs. } \\
\text { S. glaseri was only highly } \\
\text { virulent towards RPW } \\
\text { larvae only. }\end{array}$ & $\begin{array}{l}\text { P. luminescens } \\
\text { subsp. } \\
\text { laumondii } \\
\text { P. luminescens } \\
\text { X. nematophila } \\
\text { X. bovieni } \\
\text { X. ehlersii } \\
\text { X. kozodoii }\end{array}$ & $\begin{array}{l}\text { New Zealand } \\
\text { Italy } \\
\text { USA } \\
\text { Germany }\end{array}$ \\
\hline [114] & S.carpocapsae & $\begin{array}{l}\text { An alternate application } \\
\text { of EPNs and } \\
\text { Imidacloprid on the } \\
\text { canary palm as a } \\
\text { preventive treatment }\end{array}$ & $\begin{array}{l}\text { Combination applied } \\
\text { treatments were able to } \\
\text { reduce the population } \\
\text { RPWs }\end{array}$ & $\mathrm{N} / \mathrm{A}$ & Spain \\
\hline [115] & Steinernema carpocapsae & $\begin{array}{l}\text { Product Biorend }{ }^{\circledR} \text { was } \\
\text { sprayed onto the canary } \\
\text { palm. Nine larvae each } \\
\text { palm. Period: Inspection } \\
\text { after } 14 \text { and } 28 \text { days } \\
\text { post-infection }\end{array}$ & $\begin{array}{c}\text { Restorative and } \\
\text { inhibitory of EPNs were } \\
\text { at } 80 \% \text { and } 98 \% \text {, } \\
\text { respectively }\end{array}$ & X. nematophila & Spain \\
\hline
\end{tabular}


Table 1. Cont.

\begin{tabular}{|c|c|c|c|c|c|}
\hline Author & Species & Bioassay & Result & $\begin{array}{l}\text { Symbiotic } \\
\text { Bacteria }\end{array}$ & $\begin{array}{l}\text { Origin/ } \\
\text { Country }\end{array}$ \\
\hline [68] & $\begin{array}{l}\text { Heterorhabditis } \\
\text { bacteriophora }\end{array}$ & $\begin{array}{c}\text { Concentration: } 300 \text { IJs in } \\
1 \text { mL water } \\
\text { RPW: } 6 \text { th instar larvae } \\
\text { and adult } \\
\text { Duration: Mortality was } \\
\text { recorded until } 21 \text { days of } \\
\text { exposure in } \\
\text { laboratory conditions. } \\
\text { Treatment combination: } \\
\text { H. bacteriophora with } \\
\text { Bacillus thuringiesis } \\
\text { Kurstaki (70 } \mu \text { g g }{ }^{-1)} \text { and } \\
\text { H. bacteriophora with } \\
\text { Beauveria bassiana } \\
\left(1 \times 10^{7} \text { conidia } \mathrm{mL}^{-1}\right)\end{array}$ & $\begin{array}{c}\text { Mortality percentage of } \\
\text { RPW larvae and adults } \\
\text { was } 92.40 \% \text { and } 81.29 \% \text {, } \\
\text { respectively } \\
\text { Mortality percentage of } \\
\text { RPW larvae: } \\
93.35-100 \% \text { (EPN + Bt-k) } \\
\text { and } 100 \%(\mathrm{EPN}+ \\
\text { B. bassiana) } \\
\text { Mortality percentage of } \\
\text { RPW adult: } \\
\text { 81.27-94.24\% (EPN + } \\
\text { Bt-k) and } 100 \%(\mathrm{EPN}+ \\
\text { B. bassiana) }\end{array}$ & $\mathrm{N} / \mathrm{A}$ & Pakistan \\
\hline [116] & $\begin{array}{c}\text { Heterorhabditis } \\
\text { bacteriophora-HP-88 }\end{array}$ & $\begin{array}{l}\text { Laboratory condition: } \\
\text { Concentration: } 250,500, \\
\text { 1000, 1500, and } \\
\text { 2000 IJs/mL } \\
\text { RPW: 4th, 8th, 11th } \\
\text { instars larvae and adults } \\
\text { Duration: Mortality was } \\
\text { recorded } 24 \text { h till } 9 \text { days } \\
\text { post-treatment } \\
\text { Field condition: } \\
\text { Concentration: } \\
\text { 2000 IJs / mL } \\
\text { Infested tree: Five } \\
\text { infested date palm, } \\
\text { Phoenix dactylifera } \\
\text { injected with IJs. Each } \\
\text { tree received } \\
\text { approximately } 2 \text { L of } \\
\text { EPN solution. } \\
\text { Duration: Infestation } \\
\text { was monitored every } \\
\text { week until recovery }\end{array}$ & $\begin{array}{c}\text { Mortality percentage of } \\
4 \text { th instar larvae was } \\
100 \% \text { for all } \\
\text { concentrations., while } \\
\text { LC }_{50} \text { for } 8 \text { th, } 11 \text { th, and } \\
\text { adults was } \\
435.16 \mathrm{IJs} / \mathrm{mL} \text {, } \\
1045.34 \mathrm{IJ} / \mathrm{mL} \text {, and } \\
167.90 \mathrm{IJs} / \mathrm{mL}, \\
\text { respectively } \\
\text { No external sign of } \\
\text { recovery for three weeks } \\
\text { of observations }\end{array}$ & $\mathrm{N} / \mathrm{A}$ & Egypt \\
\hline
\end{tabular}

\section{Formulation}

EPNs can be stored and large-scale produced as biopesticides in two ways, in vivo and in vitro [117]. The production of EPNs has enabled at least 13 species of Steinernematids and Heterorhabditids to be commercialized for biological insect control purposes [118]. For small-scale experiments such as laboratory bioassay with low dosage and mortality, the EPN can be inoculated on a dish and absorbent paper before being transferred to White Trap for in vivo harvesting. This method is dependent on environmental conditions that affect yields, such as optimal temperature, proper aeration, and moisture [117]. On the other hand, in vitro methods can offer mass production of the nematodes to fulfill the demanding needs for EPN application in the field. The rearing of nematodes via in vitro methods does not require insects as hosts but through solid or liquid culture [119]. In vitro reliable culture methods are performed by rearing the nematode with respective symbiotic bacteria in a growth medium. In contrast, nematodes are cultured in vitro liquid culture methods after the symbiotic bacteria were introduced in the liquid culture [120]. Next, the mass-produced nematode will be transformed into a new entity or product that practical methods can apply. This process is known as EPN formulation [121] and involves inclusions of carriers, 
additives, and active ingredients. Various forms and mediums have been used to store and transport EPNs, including aqueous suspension, synthetic sponges, gels, clay, powder, and infected cadaver [122]. These formulations are widely used and commercialized in other countries; for instance, $S$. carpocapsae was commercialized byproduct Sanoplant from Switzerland, Helix from Canada, ORTHO Biosafe USA from the USA, and BASF from Germany [97,122].

\section{Conclusions}

Rhynchophorus ferrugineus is indeed a ferocious pest in palm trees worldwide. $R$. ferrugineus infestation creates a substantial economic impact on the plantation and food supply. Many infested trees need to be cut down to prevent dispersion towards other trees. Moreover, farmers and planters have to spend more on preventive and curative treatments to prevent the infestation from spreading. Although chemical treatments are effective, they have numerous drawbacks, including pest resistance, worker's health, and environmental concerns. Therefore, alternative methods can provide a safer approach yet more effective in overcoming this infestation case of $R$. ferrugineus. Microbial entomopathogens are effective biological control agents since each organism has its approach and strategies for invading its potential host. Entomopathogenic nematodes (EPNs) are proven to be effective biological control agents in managing RPW infestation in various studies. EPNs and their symbiotic bacteria are the significant mutualistic duo that can give promising results in overcoming this infestation issue of $R$. ferrugineus. For a more specific outcome, many approaches can be explored in leveraging the pathogenicity properties of the EPNs and their symbiotic bacteria.

Author Contributions: W.N.-K. wrote a major part of the article. I.B., M.S.M., Z.O. and J.J. provided ideas and made critical corrections in this paper. S.N.A.A.-H. provided supportive information on EPN. All authors have read and agreed to the published version of the manuscript.

Funding: This research was funded by the Fundamental Research Grant Scheme (FRGS) from the Ministry of Higher Education Malaysia (Grant No. FRGS/1/2019/STG03/UKM/02/8).

Institutional Review Board Statement: Not applicable.

Informed Consent Statement: Not applicable.

Conflicts of Interest: The authors declare no conflict of interest. The funders had no role in the design of the study; in the collection, analyses, or interpretation of data; in the writing of the manuscript, or in the decision to publish the results.

\section{References}

1. EPPO. Rhynchophorus ferrugineus. 2021. Available online: https://gd.eppo.int (accessed on 2 February 2021).

2. Murphy, S.T.; Briscoe, B.R. The red palm weevil as an alien invasive: Biology and the prospects for biological control as a component of IPM. Biocontrol News Inf. 1999, 20, 35-46.

3. Faleiro, J.R. A review of the issues and management of the red palm weevil Rhynchophorus ferrugineus (Coleoptera: Rhynchophoridae) in coconut and date palm during the last one hundred years. Int. J. Trop. Insect Sci. 2006, 26, 135-154. [CrossRef]

4. Wattanapongsiri, A. A revision of the genera Rhynchophorus and Dynamis (Coleoptera: Curculionidae); Oregon State University: Corvallis, OR, USA, 1966.

5. FAO. Red Palm Weevil: Guidelines on Management Practices; FAO: Rome, Italiy, 2020; ISBN 9789251321898.

6. Wahizatul, A.A.; Chong, J.L.; Hazlina, A.Z.; Norhayati, Y.; Wan Bayani, W.O.; Yong, K.W.; Ainatun, N.Z.; Mohd, H.H. The red palm weevil, Rhynchophorus ferrugineus: Current issues and challenges in Malaysia. Oil Palm Bull. 2017, 74, 17-24.

7. Milosavljević, I.; El-Shafie, H.A.F.; Faleiro, J.R.; Hoddle, C.D.; Lewis, M.; Hoddle, M.S. Palmageddon: The wasting of ornamental palms by invasive palm weevils, Rhynchophorus spp. J. Pest Sci. 2019, 92, 143-156. [CrossRef]

8. Faleiro, J.R.; Abdallah, A.B.; El-Bellaj, M.; Al-Ajlan, A.M.; Oihabi, A. Threat of the red palm weevil, Rhynchophorus ferrugineus (Olivier) to date palm plantations in North Africa. Arab J. Plant Prot. 2012, 30, 274-280.

9. Dembilio, O.; Jacas, J.A. Bio-ecology and integrated management of the red palm weevil, Rhynchophorus ferrugineus (Coleoptera: Curculionidae), in the region of Valencia (Spain). Hell. Plant Prot. J. 2012, 5, 1-12.

10. Cuthbertson, A.G.S.; Audsley, N. Further screening of entomopathogenic fungi and nematodes as control agents for Drosophila Suzukii. Insects 2016, 7, 24. [CrossRef]

11. Ruiu, L. Insect pathogenic bacteria in integrated pest management. Insects 2015, 6, 352-367. [CrossRef] 
12. Thomas, M.C. Giant Palm Weevils of the Genus Rhynchophorus (Coleoptera: Curculionidae) and Their Threat to Florida Palms; Pest Alert DACS-P-01682; Florida Department of Agriculture and Consumer Services: Tallahassee, FL, USA, 2010; pp. 1-2.

13. Giblin-Davis, R.M.; Howard, F.W. Vulnerability of stressed palms to attack by Rhynchophorus cruentatus (Coleoptera: Curculionidae) and insecticidal control of the pest. J. Econ. Entomol. 1989, 82, 1185-1190. [CrossRef]

14. EPPO. Rhynchophorus palmarum. 2021. Available online: https://gd.eppo.int/ (accessed on 20 February 2021).

15. Hoddle, M.S.; Hoddle, C.D. Palmageddon: The invasion of California by the South American palm weevil is underway. CAPCA ADVISER 2017, 20, 40-44.

16. Giblin-Davis, R.M.; Faleiro, J.R.; Jacas, J.A.; Peña, J.E.; Vidyasagar, P.S.P.V. Biology and management of the red palm weevil, Rhynchophorus ferrugineus. In Potential Invasive Pests of Agricultural Crops; Peña, J.E., Ed.; CAB International: Oxfordshire, UK, 2013; pp. 1-34, ISBN 9781845938291.

17. Tanyi Tambe, J.; Riolo, P.; Okolle, J.N.; Isidoro, N.; Fanciulli, P.P.; Dallai, R. Sexual size differences and colour polymorphism of Rhynchophorus phoenicis in the southwest region of Cameroon. Bull. Insectol. 2013, 66, 153-159.

18. Egonyu, J.P.; Gitonga, K.J.; Khamis, F.M.; Copeland, R.S.; Finyange, P.; Odhiambo, R.; Ddamulira, G.; Tanga, C.M.; Subramanian, S. Trapping, identification and rearing of edible palm weevils in Kenya and Uganda. J. Insects Food Feed 2021, 7, $1243-1253$. [CrossRef]

19. Hoddle, M.S.; Hoddle, C.D. How far can the palm weevil, Rhynchophorus vulneratus (Coleoptera: Curculionidae), fly? J. Econ. Entomol. 2016, 109, 629-636. [CrossRef]

20. Hoddle, M.S.; Hoddle, C.D.; Alzubaidy, M.; Kabashima, J.; Nisson, J.N.; Millar, J.; Dimson, M. The palm weevil Rhynchophorus vulneratus is eradicated from Laguna Beach. Calif. Agric. 2016, 71, 23-29. [CrossRef]

21. Hallett, R.H.; Crespi, B.J.; Borden, J.H. Synonymy of Rhynchophorus ferrugineus (Olivier), 1790 and R. vulneratus (Panzer), 1798 (Coleoptera, Curculionidae, Rhynchophorinae). J. Nat. Hist. 2004, 38, 2863-2882. [CrossRef]

22. Rugman-Jones, P.F.; Hoddle, C.D.; Hoddle, M.S.; Stouthamer, R. The lesser of two weevils: Molecular-genetics of pest palm weevil populations confirm Rhynchophorus vulneratus (Panzer 1798) as a valid species distinct from R. ferrugineus (Olivier 1790), and reveal the global extent of both. PLoS ONE 2013, 8, e78379. [CrossRef]

23. Aman-Zuki, A.; Ghazali, S.Z.; Badrulisham, A.S.; Hazmi, I.R.; Nurul Wahida, O.; Yaakop, S. Proof on the divergence times of two sympatric species, Rhynchophorus ferrugineus and R. vulneratus (Coleoptera: Curculionidae) by molecular clock analysis. J. Entomol. Res. Soc. 2021, 23, 11-26. [CrossRef]

24. Buxton, P.A. Insect pests of dates and the date palm in Mesopotamia and elsewhere. Bull. Entomol. Res. 1920, 11, 287-303. [CrossRef]

25. Cox, M.L. Red Palm Weevil, Rhynchophorus ferrugineus in Egypt. FAO Plant Prot. Bull. 1993, 41, 30-31.

26. Barranco, P.; de la Pena, J.; Cabello, T. Un nuevo curculio'nido tropical para la fauna europa, Rhynchophorus ferrugineus (Olivier 1790), (Curculionidae: Coleoptera). Bol. De La Asoc. Esp. De Entomol. 1995, 20, 257-258.

27. Jalinas, J.; Güerri-agulló, B.; Dosunmu, O.G.; Llorca, L.V.L.; Mankin, R.W.; Red, T.; Weevil, P.; Olivier, R. Acoustic activity cycles of Rhynchophorus ferrugineus (Coleoptera: Dryophthoridae) early instars after Beauveria bassiana (Hypocreales: Clavicipitaceae) treatments. Ann. Entomol. Soc. Am. 2017, 110, 551-557. [CrossRef]

28. Fiaboe, K.K.M.; Peterson, A.T.; Kairo, M.T.K.; Roda, A.L. Predicting the potential worldwide distribution of the red palm weevil Rhynchophorus ferrugineus (Olivier) (Coleoptera: Curculionidae) using ecological niche modelling. Fla. Entomol. 2012, 95, 659-673. [CrossRef]

29. Ge, X.; He, S.; Wang, T.; Yan, W.; Zong, S. Potential distribution predicted for Rhynchophorus ferrugineus in China under different climate warming scenarios. PLoS ONE 2015, 10, e0141111. [CrossRef] [PubMed]

30. Abraham, A.V.; al Shuaibi, M.A.; Faleiro, J.R.; Abozuhairah, R.A.; Vidyasagar, P.S.P.V. An integrated management approach for red palm weevil Rhynchophorus ferrugineus Oliv. a key pest of date palm in the Middle East. J. Agric. Mar. Sci. 1998, 3, 77-83. [CrossRef]

31. Martin, B.; Juliet, V. A novel approach to identify red palm weevil on palms. Adv. Mater. Res. 2013, 634-638, 3853-3857. [CrossRef]

32. El-sabea, A.M.R.; Faleiro, J.R.; Abo-el-saad, M.M. The threat of red palm weevil Rhynchophorus ferrugineus to date plantations of the Gulf region in the Middle-East: An economic perspective. Outlooks Pest Manag. 2009, 20, 131-134. [CrossRef]

33. Al-Nujiban, A.A.; Aldosari, S.A.; Al-Suhaibani, A.M.; Abdel-Azim, M.M.; Mostafa Ibrahim, S.M.; Shukla, P. Effect of date palm cultivar on fecundity and development of Rhynchophorus ferrugineus. Bull. Insectol. 2015, 68, 199-206.

34. Gozel, U.; Gozel, C.; Yurt, C.; Inci, D. Efficacy of entomopathogenic nematodes on the red palm weevil Rhynchophorus ferrugineus (Olivier, 1790) (Coleoptera: Curculionidae) larvae. Int. J. Bioassay 2015, 4, 4436-4439. [CrossRef]

35. Yong, W.K.; Aisyah, A.B.; Wahizatul, A.A. Fecundity, fertility and survival of red palm weevil (Rhynchophorus ferrugineus) larvae reared on sago palm. Sains Malays. 2015, 44, 1371-1375. [CrossRef]

36. Wahizatul, A.A.; Zazali, C.; Abdul Rahman, A.R.; Nurul Izzah, A.G. A new invasive coconut pest in Malaysia: The red palm weevil (Curculionidae: Rhynchophorus ferrugineus). Plant 2013, 89, 97-110.

37. Witt, A.; Hula, V.; Suleiman, A.S.; van Damme, K. First record of the red palm weevil Rhynchophorus ferrugineus (Olivier) on Socotra Island (Yemen), an exotic pest with high potential for adverse economic impacts. Rend. Lincei. Sci. Fis. E Nat. Vol. 2020, 31, 645-654. [CrossRef] 
38. Dembilio, O.; Jacques, J.A. Biology and management of red palm weevil. In Sustainable Pest Management in Date Palm: Current Status and Emerging Challenges; Wakil, W., Faleiro, J.R., Miller, T.A., Eds.; Springer: Dordrecht, The Netherlands, 2015; pp. 13-35, ISBN 9783319243979.

39. Ju, R.-T.; Wang, F.; Wan, F.-H.; Li, B. Effect of host plants on development and reproduction of Rhynchophorus ferrugineus (Olivier) (Coleopteraa: Curculionidae). J. Pest Sci. 2011, 84, 33-39. [CrossRef]

40. Norzainih, J.J.; Harris, M.N.; Nurul Wahida, O.; Salmah, Y.; Norefrina Shafinaz, M.N. Continuous rearing of the red palm weevils, Rhynchophorus ferrugineus (Olivier), 1970 on sugarcane in laboratory for biological studies (Coleoptera: Dryophthoridae) In Proceedings of the 3rd International Conference on Chemical, Agricultural and Medical Sciences, 10-11 December 2015; pp. 38-40.

41. El-Zoghby, I.R.M.; Abdel-Hameid, N.F. Rearing of the red palm weevil, Rhynchophorus ferrugineus (Olivier) on Different Natural Diets. In Proceedings of the 4th International Conference on Biotechnology Applications in Agriculture (ICBAA), Benha University, Moshtohor and Hurghada, Egypt, 4-7 April 2018; pp. 509-518.

42. Hussain, A.; Rizwan-ul-Haq, M.; Al-Jabr, A.M.; Al-Ayied, H.Y. Managing invasive populations of red palm weevil: A worldwide perspective. J. Food Agric. Environ. 2013, 11, 456-463.

43. Salama, H.S.; Abdel-Razek, A.S. Development of the red palm weevil, Rhynchophorus ferrugineus (Olivier), (Coleoptera, Curculionidae) on natural and synthetic diets. J. Pest Sci. 2002, 75, 137-139. [CrossRef]

44. Güerri-Agulló, B.; Gómez-Vidal, S.; Asensio, L.; Barranco, P.; Lopez-Llorca, L.V. Infection of the red palm weevil (Rhynchophorus ferrugineus) by the entomopathogenic fungus Beauveria bassiana: A SEM study. Microsc. Res. Tech. 2010, 73, 714-725. [CrossRef]

45. Harith-Fadzilah, N.; Harris-Hussain, M.; Idris, A.G.; Azlina, Z.; Samsudin, A.; Zamri, Z.; Wahizatul, A.A.; Jalinas, J.; Maizom, H. Physical and physiological monitoring on red palm weevil-Infested oil palms. Insects 2020, 11, 407. [CrossRef]

46. Chihaoui-Meridja, S.; Harbi, A.; Abbes, K.; Chaabane, H.; la Pergola, A.; Chermiti, B.; Suma, P. Systematicity, persistence and efficacy of selected insecticides used in endotherapy to control the red palm weevil Rhynchophorus ferrugineus (Olivier, 1790) on Phoenix canariensis. Phytoparasitica 2020, 48, 75-85. [CrossRef]

47. Al-Dosary, N.M.N.; Al-Dobai, S.; Faleiro, J.R. Review on the management of red palm weevil Rhynchophorus ferrugineus Olivier in date palm Phoenix dactylifera L. Emir. J. Food Agric. 2016, 28, 34-44. [CrossRef]

48. Haris, M.H.; Nang, M.L.S.; Chuah, T.S.; Wahizatul, A.A. The efficacy of synthethic food baits in capturing red palm weevil, Rhynchophorus ferrugineus (Coleoptera: Curculionidae) in campus area of Universiti Malaysia Terengganu. Serangga 2014, 19, 19-35.

49. Faleiro, J.R.; Al-Shawaf, A.M.; Al-Dandan, A.M.; Al-Odhayb, A.; Al-Rudayni, A.; Abdallah, A.B.; Peixoto, M.P.; Vargas, R.; Bottom, M.; Chidi, S.; et al. Controlled release products for managing insect pests. Outlooks Pest Manag. 2016, 27, 175-180. [CrossRef]

50. Jalinas, J.; Guerri-Agullo, B.; Dosunmu, O.G.; Haseeb, M.; Lopez-Llorca, L.V.; Mankin, R.W. Acoustic signal applications in detection and management of Rhynchophorus spp. in fruit-crops and ornamental palms. Fla. Entomol. 2019, 102, 475-479. [CrossRef]

51. Jalinas, J.; Guerri-Agullo, B.; Mankin, R.W.; Lopez-Follana, R.; Lopezz_Llorca, L.V. Acoustic assessment of Beauveria bassiana (Hypocrealess: Clavicipitaceae) effects on Rhynchophorus ferrugineus (Coleoptera: Dryophthoridae) larval activity and mortality. J. Econ. Entomol. 2015, 108, 444-453. [CrossRef] [PubMed]

52. Mankin, R.W. Applications of acoustics in insect pest management. CAB Rev. 2012, 7, 1-7. [CrossRef]

53. DOA. Report on Current Status of Attack of the Red Palm Weevil, Rhynchophorus ferrugineus in Terengganu; Department of Agriculture Malaysia: Kuching, Malaysia, 2019.

54. Santhi, S.V.; Salame, L.; Nakache, Y.; Koltai, H.; Soroker, V.; Glazer, I. Attraction of entomopathogenic nematodes Steinernema carpocapsae and Heterorhabditis bacteriophora to the red palm weevil (Rhynchophorus ferrugineus). Biol. Control 2015, 83, 75-81. [CrossRef]

55. Manzoor, M.; Ahmad, J.; Sharif, Z.M.; Majeed, D.; Kiran, H.; Ali, M.J. Comparative effectiveness of entomopathogenic nematodes against red palm weevil (Rhynchophorus ferrugineus) in Pakistan. J. Entomol. Zool. Stud. 2017, 5, 756-760.

56. Dembilio, Ó.; Quesada-moraga, E.; Santiago-álvarez, C.; Jacas, J.A. Potential of an indigenous strain of the entomopathogenic fungus Beauveria bassiana as a biological control agent against the red palm weevil, Rhynchophorus ferrugineus. J. Invertebr. Pathol. 2010, 104, 214-221. [CrossRef]

57. Yasin, M.; Wakil, W.; Ghazanfar, M.U.; Qayyum, M.A.; Tahir, M.; Bedford, G.O. Virulence of entomopathogenic fungi Beauveria bassiana and Metarhizium anisopliae against red palm weevil, Rhynchophorus ferrugineus (Olivier). Entomol. Res. 2017, 49, 3-12. [CrossRef]

58. Ishak, I.; Ng, L.C.; Harris-Hussain, M.; Jalinas, J.; Idris, A.B.; Azlina, Z.; Samsudin, A.; Wahizatul, A.A. Pathogenicity of an indigenous strain of the entomopathogenic fungus Metarhizium anisopliae (Hypocrealess: Clavicipitaceae) (MET-GRA4 Strain) as a potential biological control agent against the red palm weevil (Coleoptera: Dryophthoridae). J. Econ. Entomol. 2020, 113, 43-49. [CrossRef]

59. Gopinadhan, P.B.; Mohandas, N.; Vasudevan Nair, K.P. Cytoplasmic polyhedrosis virus infecting redpalm weevil of coconut. Curr. Sci. 1990, 59, 577-580.

60. Mazza, G.; Francardi, V.; Simoni, S.; Benvenuti, C.; Cervo, R.; Faleiro, J.R.; Llacer, E.; Longo, S.; Nannelli, R.; Tarasco, E.; et al. An overview on the natural enemies of Rhynchophorus palm weevils, with focus on R. ferrugineus. Biol. Control 2014, 77, 83-92. [CrossRef] 
61. Alfazariy, A.A. Notes on the survival capacity of two naturally occurring entomopathogens on the red palm weevil Rhynchophorus ferrugineus (Olivier) (Coleoptera: Curculionidae). Egypt. J. Biol. Pest Control 2004, 14, 423.

62. Martinez de Altube, M.; Peña, A.M. Use of entomopathogenic nematodes and chitosan against Rhynchophorus ferrugineus and Paysandisia archon in Phoenix canariensis, Pheonix dactilifera and Chamaerops humilis in Spain. Insect Pathog. Insect Parasit. Nematodes IOBC/Wprs Bull. 2009, 45, 369-370.

63. Yasin, M.; Wakil, W.; Qayyum, M.A.; Ali, S.; Sajjad, A.; Aqueel, M.A.; Shakeel, M. Biocontrol potential of entomopathogenic fungi, nematodes and bacteria against Rhynchophorus ferrugineus (Olivier). Egypt. J. Biol. Pest Control. 2021, 31, 138-149. [CrossRef]

64. Ali, I.A.; Al-Jabr, A.; Memari, A.R. FDTD Simulation and experimental investigation of controlled microwave irradiation of red palm weevils. In Proceedings of the IEEE Middle East Conference on Antennas and Propagation (MECAP 2010), Cairo, Egypt 20-22 October 2010; pp. 1-8.

65. Massa, R.; Panariello, G.; Migliore, M.D.; Pinchera, D.; Schettino, F.; Griffo, R.; Martano, M.; Power, K.; Maiolino, P.; Caprio, E. Microwave heating: A promising and eco-compatible solution to fight the spread of red palm weevil. Arab J. Plant Prot. 2019, 37, 143-148. [CrossRef]

66. Massa, R.; Panariello, G.; Pinchera, D.; Schettino, F.; Caprio, E.; Griffo, R.; Migliore, M.D. Experimental and numerical evaluations on palm microwave heating for red palm weevil pest control. Sci. Rep. 2017, 7, 1-8. [CrossRef]

67. Massa, R.; Caprio, E.; de Santis, M.; Griffo, R.; Migliore, M.D.; Panariello, G.; Pinchera, D.; Spigno, P. Microwave treatment for pest control: The case of Rhynchophorus ferrugineus in Phoenix Canar. EPPO Bull. 2011, 41, 128-135. [CrossRef]

68. Fabrick, J.A.; Yool, A.J.; Spurgeon, D.W. Insecticidal activity of marigold Tagetes patula plants and foliar extracts against the Hemipteran pests, Lygus hesperus and Bemisia tabaci. PLoS ONE 2020, 15, e0233511. [CrossRef]

69. Samarasekera, R.; Kalhari, K.S. Insecticidal activity of essential oils of Ceylon Cinnamomum and Cymbopogon Species against Musca domestica. J. Essent. Oil Res. 2006, 18, 352-354. [CrossRef]

70. Doumbia, M.; Yoboue, K.; Kouame, L.K.; Kanko, C.; Kra, D.K.; Kwadjo, K.E.; Douan, B.G.; Dagnogo, M. Toxicity of Cymbopogon nardus (Glumaless: Poacea) against four stored food products insect pests. Int. J. Farming Allied Sci. 2014, 3, 903-909.

71. Hernandez-Lambraño, R.; Pajaro-Castro, N.; Caballero-Gallardo, K.; Stashenko, E.; Olivero-Verbel, J. Essential oils from plants of the genus Cymbopogon as natural insecticides to control stored product pests. J. Stored Prod. Res. 2015, 62, 81-83. [CrossRef]

72. Mona, M.A.D. Insecticidal potential of cardamom and clove extracts on adult red palm weevil Rhynchophorus ferrugineus. Saudi J. Biol. Sci. 2020, 27, 195-201. [CrossRef]

73. Kanzaki, N.; Kiontke, K.; Tanaka, R.; Hirooka, Y.; Schwarz, A.; Müller-Reichert, T.; Chaudhuri, J.; Pires-Dasilva, A. description of two three-gendered nematode species in the new genus Auanema (Rhabditina) that are models for reproductive mode evolution. Sci. Rep. 2017, 7, 11135. [CrossRef] [PubMed]

74. Ye, W.; Robbins, R.T.; Kirkpatrick, T. Molecular characterization of root-knot nematodes (Meloidogyne spp.) from Arkansas, USA Sci. Rep. 2019, 9, 15680. [CrossRef]

75. Elawad, S.A.; Gowen, S.R.; Hague, N.G.M. The life cycle of Steinernema abbasi and S. riobrave in Galleria mellonella. Nematology 1999, 1, 762-764. [CrossRef]

76. Nguyen, K.B.; Smart, G.C. Life cycle of Steinernema scapterisci Nguyen \& Smart 1990. J. Entomol. 1992, $24,160-169$.

77. Tarasco, E.; Clausi, M.; Rappazzo, G.; Panzavolta, T.; Curto, G.; Sorino, R.; Oreste, M.; Longo, A.; Leone, D.; Tiberi, R.; et al. Biodiversity of entomopathogenic nematodes in Italy. J. Helminthol. 2015, 89, 359-366. [CrossRef]

78. Stuart, R.J.; Barbercheck, M.E.; Grewal, P.S. Entomopathogenic nematodes in the soil environment: Distributions, interactions and the influence of biotic and abiotic factors. In Nematode Pathogenesis of Insects and Other Pests; Campos-Herrera, R., Ed.; Springer International Publishing AG: Cham, Switzerland, 2015; pp. 97-137, ISBN 9783319182667.

79. Kaya, H.K.; Stock, S.P. Techniques in insect nematology. In Manual of Techniques in Insect Pathology; Lacey, L.A., Ed.; Academic Press: London, UK, 1997; pp. 281-324.

80. Gozel, U.; Gozel, C. Entomopathogenic nematodes in pest management. In Integrated Pest Management (IPM): Environmentally Sound Pest Management; Gill, H., Ed.; IntechOpen: London, UK, 2016; pp. 55-69.

81. Stock, S.P.; Hunt, D.J. Morphology and systematics of nematodes used in biocontrol. In Nematodes as Biocontrol Agents; Grewal, P.S., Ehlers, R.U., Shapiro-Ilan, D.I., Eds.; CAB International: Oxfordshire, UK, 2005; pp. 3-45.

82. Hunt, D.J.; Nguyen, K.B. Advances in Entomopathogenic Nematodes Taxonomy and Phylogeny. In Nematology Monographs and Perspectives; Brill: Leiden, The Netherlands, 2016; p. 2. ISBN 9789004285347.

83. Bird, A.F.; Bird, J. The Structure of Nematodes; Academic Press: San Diego, CA, USA, 1991; ISBN 0120996510.

84. Akhurst, R.J. A Xenorhabdus sp. (Eubacteriales: Enterobacteriaceae) symbiotically associated with Steinernema kraussei (Nematoda: Steinernernatidae). Rev. De Nematol. 1982, 5, 277-280.

85. Kaya, H.K.; Gaugler, R. Nematodes. Annu. Rev. Entomol. 1993, 38, 181-206. [CrossRef]

86. Lee, D.L. The Biology of Nematodes; Taylor \& Francis: New York, NY, USA, 2002; ISBN 0-203-26116-X.

87. Park, Y.; Kim, Y. Eicosanoids rescue Spodoptera exigua infected with Xenorhabdus nematophilus, the symbiotic bacteria to the entomopathogenic nematode Steinernema carpocapsae. J. Insect Physiol. 2000, 46, 1469-1476. [CrossRef]

88. Thanwisai, A.; Tandhavanant, S.; Saiprom, N.; Waterfield, N.R.; Ke, P.; Bode, H.B.; Peacock, S.J.; Chantratita, N. Diversity of Xenorhabdus and Photorhabdus spp. and their symbiotic entomopathogenic nematodes from Thailand. PLoS ONE 2012, 7, e43835. [CrossRef] [PubMed] 
89. Yooyangket, T.; Muangpat, P.; Polseela, R.; Tandhavanant, S.; Thanwisai, A.; Vitta, A. Identification of entomopathogenic nematodes and symbiotic bacteria from Nam Nao National Park in Thailand and larvicidal activity of symbiotic bacteria against Aedes aegypti and Aedes albopictus. PLoS ONE 2018, 13, e0195681. [CrossRef]

90. Griffin, C.T.; Boemare, N.E.; Lewis, E.E. Biology and behaviour. In Nematodes as Biocontrol Agents; Grewal, P.S., Ehlers, R.U., Shapiro-Ilan, D.I., Eds.; CAB International: Oxfordshire, UK, 2005; pp. 47-64.

91. Tailliez, P.; Laroui, C.; Ginibre, N.; Paule, A.; Pages, S.; Boemarare, N. Phylogeny of Photorhabdus and Xenorhabdus based on universally conserved protein-coding sequences and implications for the taxonomy of these two genera. Proposal of new taxa: X.vietnamensis sp. nov., P. luminescens subsp. caribbeanensis subsp. nov., P. luminescens subsp. hainanensis subsp. nov., P. temperata subsp. khanii subsp. nov., P. temperata subsp. tasmaniensis subsp. nov., and the reclassification of $P$. luminescens subsp. thracensis as P. temperata subsp. thracensis comb. nov. Int. J. Syst. Evol. Microbiol. 2010, 60, 1921-1937. [CrossRef] [PubMed]

92. Weissfeld, A.S.; Halliday, R.J.; Simmons, D.E.; Trevino, E.A.; Vance, P.H.; OHara, C.M.O.; Sowers, E.G.; Kern, R.; Koy, R.D.; Hodde, K.; et al. Photorhabdus asymbiotica, a pathogen emerging on two continents that proves that there is no substitute for a well-trained clinical microbiologist. J. Clin. Microbiol. 2005, 43, 4152-4155. [CrossRef] [PubMed]

93. Dix, I.; Burnell, A.M.; Griffin, C.T.; Joyce, S.A.; Nugent, M.J.; Downes, M.J. The identification of biological species in the genus Heterorhabditis (Nematoda: Heterorhabditidae) by cross-breeding second generation amphimictic adults. Parasitology 1992, 104, 509-518. [CrossRef]

94. Kerry, B.R.; Hominick, W.M. Biological control. In The Biology of Nematodes; Lee, D.L., Ed.; Taylor \& Francis: London, UK, 2002; pp. 932-984.

95. Poinar, G.O. Taxonomy and biology of Steinernematidae and Heterorhabditidae. In Entomopathogenie Nematodes in Biological Control; Gaugler, R., Kaya, H.K., Eds.; Taylor \& Francis: Boca Raton, FL, USA, 1990; pp. 23-59.

96. Forst, S.; Nealson, K. Molecular biology of the symbiotic-pathogenic bacteria Xenorhabdus spp. and Photorhabdus spp. Microbiol. Rev. 1996, 60, 21-43. [CrossRef]

97. Vashisth, S.; Chandel, Y.S.; Sharma, K. Entomopathogenic nematodes-A review. Agric. Rev. 2013, 34, 163-175. [CrossRef]

98. Binda-Rossetti, S.; Mastore, M.; Protasoni, M.; Brivio, M.F. Effects of an entomopathogen nematode on the immune response of the insect pest red palm weevil: Focus on the host antimicrobial response. J. Invertebr. Pathol. 2016, 133, 110-119. [CrossRef]

99. Mastore, M.; Arizza, V.; Manachini, B.; Brivio, M.F. Modulation of immune responses of Rhynchophorus ferrugineus (Insecta: Coleoptera) induced by the entomopathogenic nematode Steinernema carpocapsae (Nematoda: Rhabditida). Insect Sci. 2014, 22, 1-13. [CrossRef]

100. Wang, Y.; Gaugler, R. Steinernema glaseri surface coat protein suppresses the immune response of Popillia japonica (Coleoptera: Scarabaeidae) larvae. Biol. Control 1999, 14, 45-50. [CrossRef]

101. Kucharska, K.; Kucharski, D.; Zajdel, B. Bacteria Xenorhabdus and Photorhabdus, entomopathogenic nematodes and insects-their role in the complex symbiont-parasite-host relationship. Postepy Mikrobiol. 2015, 54, 154-164.

102. Owuama, C. Entomopathogenic symbiotic bacteria, Xenorhabdus and Photorhabdus of nematodes. World J. Microbiol. Biotechnol. 2001, 17, 505-515. [CrossRef]

103. Lacey, L.A.; Shapiro-Ilan, D.I. Microbial control of insect pests in temperate orchard systems: Potential for incorporation into IPM. Annu. Rev. Entomol. 2008, 53, 121-144. [CrossRef] [PubMed]

104. Shahina, F.; Gulsher, M.; Javed, S.; Khanum, T.A.; Bhatti, M.I. Susceptibility of different life stages of red palm weevil, Rhynchophorus ferrugineus, to entomopathogenic nematodes. Int. J. Nematol. 2009, 19, 232-239.

105. El Sadawy, H.A.; El Namaky, A.H.; Al Omari, F.; Bahareth, O.M. Susceptibility of Rhynchophorus ferrugineus (Olivier) (Coleoptera: Curculionidae) to entomopathogenic nematodes with regard to its immune response. Biol. Control 2020, 148, 104308. [CrossRef]

106. Elawad, S.A.; Mousa, S.A.; Shahdad, A.S.; Alawaash, S.A.; Alamiri, A.M.A. Efficacy of entomopathogenic nematodes against red palm weevil in UAE. Acta Hortic. 2007, 736, 415-420. [CrossRef]

107. Griffin, C.T. Perspectives on the behavior of entomopathogenic nematodes from dispersal to reproduction: Traits contributing to nematode fitness and biocontrol efficacy. J. Entomol. 2012, 44, 177-184.

108. Atwa, A.A.; Hegazi, E.M. Comparative susceptibilities of different life stages of the red palm weevil (Coleoptera: Curculionidae) treated by entomopathogenic nematodes. J. Econ. Entomol. 2014, 107, 1339-1347. [CrossRef]

109. Saleh, M.M.E.; Alheji, M. Biological control of red palm weevil with entomopathogenic nematodes in the eastern province of Saudi Arabia. Egypt. J. Biol. Pest Control 2003, 13, 55-59.

110. Abbas, M.S.T.; Hanonik, S.P. Pathogenicity of entomopathogenic nematodes to red palm weevil, Rhynchophorus ferrugineus. Int. J. Nematol. 1999, 9, 84-86.

111. Abbas, M.S.T.; Saleh, M.M.E.; Akil, A.M. Laboratory and field evaluation of the pathogenicity of entomopathogenic nematodes to the red palm weevil, Rhynchophorus ferrugineus (Oliv.) (Col.: Curculionidae). J. Pest Sci. 2001, 74, 167-168. [CrossRef]

112. Wakil, W.; Yasin, M.; Shapiro-ilan, D. Effects of single and combined applications of entomopathogenic fungi and nematodes against Rhynchophorus ferrugineus (Olivier). Sci. Rep. 2017, 7, 5971. [CrossRef] [PubMed]

113. Triggiani, O.; Tarasco, E. Evaluation of the effects of autochthonous and commercial isolates of Steinernematidae and Heterorhabditidae on Rhynchophorus ferrugineus. Bull. Insectol. 2011, 64, 175-180.

114. Tapia, G.; Ruiz, M.A.; Tellez, M.M. Recommendations for a preventive strategy to control red palm weevil (Rhynchophorus ferrugineus, Olivier) based on the use of insecticides and entomopathogenic nematodes. EPPO Bull. 2011, 41, 136-141. [CrossRef] 
115. Llácer, E.; de Altube, M.M.; Jacas, J.A. Evaluation of the efficacy of Steinernema carpocapsae in a chitosan formulation against the red palm weevil, Rhynchophorus ferrugineus, in Phoenix canariensis. BioControl 2009, 54, 559-565. [CrossRef]

116. Ali, M.A.; Bekhiet, H.K.; Ragheb, D.A.; El-Feshaway, A.A. Evaluation of some entomopathogens on the red palm weevil, Rhynchophorus ferrugineus under laboratory and field conditions. Egypt. J. Agric. Res. 2018, 96, 415-430. [CrossRef]

117. Shapiro-Ilan, D.I.; Han, R.; Dolinksi, C. Entomopathogenic nematode production and application technology. J. Nematol. 2012, 44, 206-217.

118. Shapiro-Ilan, D.I.; Morales-Ramos, J.A.; Rojas, M.G. In vivo production of entomopathogenic nematodes. In Microbial-Based Biopesticides: Methods in Molecular Biology; Glare, T.R., Moran-Diez, M.E., Eds.; Springer Science + Business Media: New York, NY, USA, 2016; Volume 1477, pp. 137-158, ISBN 9781493963676.

119. McMullen John, G.; Stock, S.P. In vivo and in vitro rearing of entomopathogenic nematodes (Steinernematidae and Heterorhabditidae). J. Vis. Exp. 2014, 91, e52096. [CrossRef]

120. Strauch, O.; Ehlers, R.U. Influence of the aeration rate on the yields of the biocontrol nematode Heterorhabditis megidis in monoxenic liquid cultures. Appl. Microbiol. Biotechnol. 2000, 54, 9-13. [CrossRef]

121. Grewal, P.S. Formulation and application technology. In Entomopathogenic Nematology; Gaugler, R., Ed.; CAB International: Oxfordshire, UK, 2002; pp. 265-287.

122. Cruz-Martínez, H.; Ruiz-Vega, J.; Matadamas-Ortíz, P.T.; Cortés-Martínez, C.I.; Rosas-Diaz, J. Formulation of entomopathogenic nematodes for crop pest control-A review. Plant Prot. Sci. 2017, 53, 15-24. [CrossRef] 